\title{
Applicability of the "Frame of Reference" approach for environmental monitoring of offshore renewable energy projects
}

\author{
Erwan Garel ${ }^{\mathrm{a}, *}$, Cibran Camba Rey ${ }^{\mathrm{b}}$, Óscar Ferreira ${ }^{\mathrm{a}}$, Mark van Koningsveld ${ }^{\mathrm{c}, \mathrm{d}}$ \\ ${ }^{a}$ Centre for Marine and Environmental Research (CIMA), Algarve University, Edifcio 7, Campus de Gambelas, 8005 - 139 Faro, Portugal \\ ${ }^{b}$ Acciona Energa S.A. Avda. Ciudad de la Innovacin 5, 31621 Sarriguren, Spain \\ ${ }^{c}$ Van Oord Dredging and Marine Contractors B.V., P.O. Box 8574, 3009 AN, Rotterdam, The Netherlands \\ ${ }^{d}$ Delft University of Technology, Faculty of Civil Engineering and Geosciences, P.O. Box 5048, 2600 GA, Delft, The Netherlands
}

\begin{abstract}
This paper assesses the applicability of the Frame of Reference (FoR) approach for the environmental monitoring of largescale offshore Marine Renewable Energy (MRE) projects. The focus is on projects harvesting energy from winds, waves and currents. Environmental concerns induced by MRE projects are reported based on a classification scheme identifying stressors, receptors, effects and impacts. Although the potential effects of stressors on most receptors are identified, there are large knowledge gaps regarding the corresponding (positive and negative) impacts. In that context, the development of offshore MRE requires the implementation of fit-for-purpose monitoring activities aimed at environmental protection and knowledge development. Taking European legislation as an example, it is suggested to adopt standardized monitoring protocols for the enhanced usage and utility of environmental indicators. Towards this objective, the use of the FoR approach is advocated since it provides guidance for the definition and use of coherent set of environmental state indicators. After a description of this framework, various examples of applications are provided considering a virtual MRE project located in European waters. Finally, some conclusions and recommendations are provided for the successful implementation of the FoR approach and for future studies.
\end{abstract}

Keywords: marine renewable energy; large-scale projects; environmental monitoring; environmental indicators; monitoring framework; frame of reference

\section{Introduction}

Offshore winds, waves and currents have a large potential for long-term electricity generation world wide (Pelc and Fujita, 2002; Thresher and Musial, 2010). The wind industry is leading the way, whilst devices to harvest offshore wave and current energy are still under development (Sutherland et al., 2008; Inger et al., 2009; Bedard et al., 2010). Offshore wind energy is harvested by turbines rotating about a horizontal axis, which are derived from the well-established technology used on land. Nowadays, commercial offshore wind turbines have seafloor foundations, the most common ones being monopiles driven into the bed, gravity-based foundations, tripod foundations and jacket foundations. However, with wind parks moving towards deeper water, various types of floating foundations are being developed (Butterfield et al., 2007; Main(e) International Consulting, 2012). For waves, the technology is relatively immature and no commercial design has emerged yet amongst the very large variety of existing concepts (see Drew et al., 2009; Bald et al., 2010). Regarding currents, the most significant technology offshore consists

\footnotetext{
* Corresponding author

Email address: : egarel@ualg.pt (Erwan Garel)
}

of rotating devices on horizontal axes (similar to wind turbines), even though other designs including vertical axes are also considered (see O'Rourke et al., 2010; Polagye et al., 2011).

As wind energy projects are moving further offshore, they are also increasing in size (see EWEA, 2012). The worlds largest (in surface area) Marine Renewable Energy (MRE) project currently operating offshore is the Greater Gabbard (southern North Sea), covering $146 \mathrm{~km}^{2}$ with a nominal capacity of $504 \mathrm{MW}$; it should be soon exceeded by the 1,000 MW London array project $\left(230 \mathrm{~km}^{2}\right.$ surface area) which is currently being developed in two phases (Phase 1: 175 turbines over $121 \mathrm{~km}^{2}$ generating $630 \mathrm{MW}$ is fully operating since April 2013). The future of both wave and tidal energy converters is also to cover such large areas including hundreds of devices (see Johnson et al., 2012). In addition, the offshore energy industry is considering large-scale (i.e., area $>10 \mathrm{~km}^{2}$, at least) multiplatform projects combining various MRE devices (e.g., wind turbines and wave converters) or activities (e.g., energy conversion and aquaculture), in order to increase the utilisation factor per site and the overall revenue. That effort is testified by the relatively large number of recent EUfunded projects related to this domain (e.g., MARINA; MERMAID; ORECA; TROPOS; H2OCEAN). 
Multi-platform or not, MRE projects are also expected to cumulate at specific locations offshore because of grid and land access considerations, together with site-specificity regarding the resource (especially for waves and currents). In the Irish Sea, for example, three windfarms are currently operating within a radius of less than $20 \mathrm{~km}$ (Walney, Barrow and Ormonde, covering an area of $73 \mathrm{~km}^{2}$, $10 \mathrm{~km}^{2}$ and $8.7 \mathrm{~km}^{2}$, respectively) and a fourth very large one is proposed (West Duddon, $66 \mathrm{~km}^{2}$ ). The development of these large-scale projects, and their addition to other anthropogenic activities offshore, is accompanied by environmental concerns (Pelc and Fujita, 2002; Gill, 2005; Michel et al., 2007; Sutherland et al., 2008; Inger et al., 2009; Masden et al., 2010; Simas et al., 2010; Wilhelmsson et al., 2010; Shields et al., 2011).

The evaluation of environmental effects in the offshore realm is a difficult task, because the marine environment is a highly complex system where physical, chemical and biological properties interact at several spatial and temporal scales. Although being ambiguously defined (Heink and Kowarik, 2010), "environmental indicators" generally reduce the complexity of a problem, or of a large number of parameters, to a smaller number of keyparameters that enable the description or quantification of the status and trends of (entire or partial) ecosystems. As such, indicators may facilitate management decisions as they provide the necessary information for decisionmakers about where, when and how to act (Gubbay, 2004; Davidson et al., 2007). They are also useful for the communication of overall progress on stated goals and benchmarks.

During the last decade, indicators have been increasingly developed, including for the marine environment (Davies et al., 2001; Gubbay, 2004), and used at global (e.g. World Bank, United Nation, Organization for Economic Co-operation and Development), regional (e.g., European Environment Agency), national and local levels, as well as in the private sector. For example, environmental indicators are commonly used by the offshore oil and gas industry to assess the impact of exploitation on the benthic ecology and water quality (e.g., Olsgard and Gray, 1995; Andrade and Renaud, 2011).

Indicators are commonly defined and organized in frameworks that facilitate their understanding and interpretation ensuring at the same time the appropriate match between end-users and scientists (Gabrielsen and Bosch, 2003; Gubbay, 2004). Frameworks can also help to understand the inter-relations between various indicators (Stegnestam, 1999). Several environmental frameworks have been proposed, depending on the application and scale of the problem considered. For example, the Drivers-Pressures-Status-Impacts-Response (DPSIR) model provides an overall approach for analysing environmental issues, generally with regards to sustainable development (Borja et al., 2006). This framework is useful as a descriptive method reporting the environmental impacts of a particular sector through the use of indicators; as such, it is largely used to report indicators set at national levels and is able to provide a link between the socioeconomic aspects of an activity and the induced environmental changes. DPSIR may be therefore well-adapted for the strategic development of the offshore MRE industry (Elliott, 2002). However, this type of framework might not be relevant -or difficult to implement- if the focus is on environmental monitoring of specific projects, where guidance is required to select specific indicators. In this case, other prescriptive and fully quantitative frameworks that explicitly link objectives and quantitative parameters are more adequate.

This paper assesses the applicability of the Frame of Reference (FoR) approach for the environmental monitoring of offshore MRE projects. Even though the proposed method is applicable to any type of offshore large-scale project, the focus is upon projects harvesting energy from winds, waves and currents (multi-platform or not).

\section{Environmental effects and impacts of offshore MRE projects}

\subsection{Classification of environmental effects}

Given the complexity of the marine environment and the multiplicity of technologies to harvest MRE, it is convenient to classify environmental effects within a framework. The framework used in the present paper is based on the one proposed by McMurray (2008) for wave converters, subsequently modified by Boehlert and Gill (2010) and by Polagye et al. (2011) for application to various MRE devices.

The framework describes environmental concerns in terms of stressors, receptors, effects and impacts. Stressors are features that may induce environmental changes. Receptors are elements of the ecosystem that may (or may not) respond to the stressor. Effects describe how the receptor is affected by the stressor, but do not indicate magnitude or significance. Impacts deal with severity, intensity or duration of the effect, and also with its direction (i.e., positive or negative). Impacts are generally recognized when the effects induce changes in specific variables that are used to define the status of the concerned receptor. These impacts can be either direct or indirect (the latter obviously being more difficult to evaluate). Indicators can be used to determine if the effects are strong enough to induce impacts and if a response is required.

\subsection{Stressors and receptors}

In the context of offshore wind, wave and current projects, six distinct stressors are identified: 


\begin{tabular}{|c|c|c|c|c|c|}
\hline & $\begin{array}{l}\text { Physical presence of } \\
\text { device }\end{array}$ & Dynamics & Release of chemicals & Generation of sound & $\begin{array}{l}\text { Electro-Magnetic } \\
\text { Fields }\end{array}$ \\
\hline $\begin{array}{l}\text { Physical } \\
\text { environment }\end{array}$ & Artificial reef & $\begin{array}{l}\text { Scouring } \\
\text { Seabed disruption } \\
\text { Hydrodynamic changes } \\
\text { Aerodynamic changes } \\
\text { Sediment dynamic } \\
\quad \text { changes }\end{array}$ & & & \\
\hline $\begin{array}{l}\text { Marine } \\
\text { mammals } \\
\text { and turtles }\end{array}$ & $\begin{array}{l}\text { Collision potential } \\
\text { Aggregation effect } \\
\text { Obstruction of migratory } \\
\quad \text { route }\end{array}$ & & & $\begin{array}{l}\text { Hearing injuries } \\
\text { Site avoidance } \\
\text { Stress increase } \\
\text { Acoustic masking }\end{array}$ & Behavioural change \\
\hline $\begin{array}{l}\text { Pelagic } \\
\text { habitat and } \\
\text { communities }\end{array}$ & $\begin{array}{l}\text { Collision potential } \\
\text { Artificial reef } \\
\text { Aggregation effect } \\
\text { No take zone } \\
\text { Steppingstone effect }\end{array}$ & $\begin{array}{l}\text { Hydrodynamic changes } \\
\text { Aerodynamic changes } \\
\text { Pressure effects near } \\
\text { rotating devices }\end{array}$ & & $\begin{array}{l}\text { Hearing injuries } \\
\text { Site avoidance } \\
\text { Stress increase } \\
\text { Acoustic masking }\end{array}$ & Behavioural change \\
\hline $\begin{array}{l}\text { Benthic } \\
\text { habitat and } \\
\text { communities }\end{array}$ & $\begin{array}{l}\text { Artificial reef } \\
\text { No take zone } \\
\text { Steppingstone effect } \\
\text { Flora and fauna impact } \\
\quad \text { by moorings }\end{array}$ & $\begin{array}{l}\text { Scouring } \\
\text { Seabed disruption } \\
\text { Hydrodynamic changes } \\
\text { Aerodynamic changes } \\
\text { Sediment dynamic } \\
\quad \text { changes }\end{array}$ & $\begin{array}{c}\text { Pollution from } \\
\text { dredging }\end{array}$ & Acoustic masking & $\begin{array}{l}\text { Behavioural change } \\
\text { Sediment temperature } \\
\quad \text { increase }\end{array}$ \\
\hline Marine birds & $\begin{array}{l}\text { Collision potential } \\
\text { Aggregation effect } \\
\text { Obstruction of migratory } \\
\text { route }\end{array}$ & & & Site avoidance & \\
\hline $\begin{array}{l}\text { Water } \\
\text { quality }\end{array}$ & $\begin{array}{l}\text { Artificial reef } \\
\text { Light reduction } \\
\text { Sediment re-suspension } \\
\quad \text { by moorings }\end{array}$ & $\begin{array}{l}\text { Seabed disruption } \\
\text { Hydrodynamic changes } \\
\text { Aerodynamic changes } \\
\text { Sediment dynamic } \\
\quad \text { changes }\end{array}$ & $\begin{array}{l}\text { Leaching } \\
\text { Spilling } \\
\text { Pollution from } \\
\quad \text { dredging } \\
\text { Pollution from } \\
\text { maintenance }\end{array}$ & & \\
\hline
\end{tabular}

Table 1: Potential effects of stressors (top row) upon receptors (far left column), associated to offshore MRE devices. For simplicity, the stressor "cumulative impacts" and the receptor "ecosystem interactions" are not included. Environmental effects and main potential impacts are discussed in more detail in subsection 2.3.

1. physical presence of (fixed and moving) parts of the devices in the water and in the air (including the introduction of material or substrate at the bed);

2. dynamics, which relates to (near- and far-field) changes in the air and water pressure fields and in sediment dynamics (including changes in sediment distribution due to seabed disruption during construction);

3. release of chemicals in the area from the equipment and vehicles linked to the activity and from seabed removal;

4. generation of sound, both above and under water;

5. Electro-Magnetic Fields, produced by cables (during the operational phase); and

6. cumulative impacts of stressors from several largescale projects and other human activities.

For each stressor, the stage of development of the project (survey, construction, operation and maintenance, and decommissioning) should be considered, together with the time scale (duration and frequency) and spatial extent. Both the time scale and spatial extent are highly projectand site-specific (e.g., the construction phase may take years to complete in the case of very large projects), and are not considered in this paper (for detailed information, see Wilhelmsson et al., 2010).

Seven groups of receptors are considered with respect to MRE activities:

1. the physical environment, i.e. the atmospheric and marine (wave and current) climates and the bed sediment (near-field and far-field);

2. marine mammals and sea turtles;

3. pelagic habitat and communities, including planktonic and nektonic organisms (excluding marine mammals and sea turtles);

4. benthic habitat and communities, including macrophytes, invertebrates and vertebrates living in association to bed sediment;

5. marine birds, living or migrating near the project area;

6. water quality, measured based on its physical and chemical properties; and,

7. ecosystem interactions, such as (but not only) food web interactions, and trophic dynamics. 
Amongst these receptors, marine birds, marine mammals and sea turtles are often protected by specific environmental policies, conventions and international agreements. For this reason (and also due to public perception) they are of particular importance for the development of offshore MRE projects. Due to their potential impacts on specific pelagic and benthic receptors (habitats and communities), large scale projects may indirectly change ecological processes and dynamics of marine food webs (e.g., cascading effects). The response of this receptor group ("ecosystem interactions") to stresses is the most difficult to evaluate, because of its complexity and also because impacts may occur even if no discernible changes are observed on other receptors.

\subsection{Environmental effects and main potential im- pacts}

The potential effects of stressors upon receptors at offshore MRE projects were identified based on a literature review and reported in Table 1 . Information from the following sources was used: CMACS (2003); Gill (2005); Gill et al. (2005); Hastings and Popper (2005); Zucco et al. (2006); BSH (2007); Linley et al. (2007); Brostrom (2008); Evans (2008); OSPAR (2008); Vize et al. (2008); Gill et al. (2009); Inger et al. (2009); USDOE (2009); Bald et al. (2010); Boehlert and Gill (2010); Mueller-Blenkle et al. (2010); Wilhelmsson et al. (2010); Normandeau et al. (2011); Shields et al. (2011); Smith et al. (2012). Although the potential effects of stressors on most receptors are identified, there are large knowledge gaps regarding the corresponding (positive and negative) impacts (Zucco et al., 2006; Inger et al., 2009; Bald et al., 2010; Boehlert and Gill, 2010; Wilhelmsson et al., 2010). To date, results from only few long-term (years) monitoring surveys at windfarms (all with fixed foundations) are available (e.g., Danish Energy Authority, 2009; Degraer and Brabant, 2009; Stenberg et al., 2011). The lack of knowledge of individual stressor impacts inhibits the realisation of adequate cumulative effects assessments (Polagye et al., 2011).

Despite large uncertainties, most of the negative environmental impacts of a single offshore MRE project are considered of small intensity, short-term and/or of limited spatial extent (see Wilhelmsson et al., 2010). One often cited potential negative impact upon marine birds results from the risk of collision with (fixed or moving) parts of the devices. Available studies indicate, however, that collisions have small impacts at a population scale level, although they can be significant for certain species (Desholm, 2009; Wilhelmsson et al., 2010). Concerns for marine birds are higher in case of fragmentation of coherent ecological units and habitat loss that can be induced by an avoidance behaviour due to the presence of the devices and to the production of noise; likewise, by deflection of migration routes, especially for daily commuting species which might not have enough energy to cope with the changes (e.g., Larsen and Guillemette, 2007; Masden et al., 2009). In general, the greatest risks faced by marine mammals are hearing injuries and habitat loss due to the production of sounds during the construction phase (Bald et al., 2010; Wilhelmsson et al., 2010), even though strikes by the blades of current devices may also be of concern in some cases (Boehlert and Gill, 2010). Furthermore, the production of noise during operation may mask bio-acoustics for communication and navigation of long-distance migrating whales and sea turtles (Samuel et al., 2005; Wilhelmsson et al., 2010). The newly constructed structures may serve as steppingstones for invasive species (dispersal effect), which might pose as a threat for local benthic and pelagic communities (Bulleri and Airoldi, 2005; Glasby et al., 2007; Wilhelmsson et al., 2010). The production of magnetic fields by cables may also modify the behaviour of resident or migratory species that use geomagnetic field for localisation and orientation (CMACS, 2003; Gill, 2005; Gill et al., 2009; Normandeau et al., 2011; Wilhelmsson et al., 2010). Overall, oil slick resulting from aircraft or ship accident is considered to have the largest potential negative impact upon all receptors in terms of duration, spatial extent and intensity (Bald et al., 2010).

The main potential positive impacts are associated with the physical presence of MRE devices. The exclusion of fishing activities, including trawling, within the project area should act as a "no take zone", with positive impacts for pelagic species (e.g., increase of fish stocks) and benthic communities with a more favourable environment for longlived rather than opportunistic species (Defew et al., 2012; Fayram and De Risi, 2007; Wilhelmsson et al., 2010). Furthermore, the introduction of hard structures (e.g., piles, foundations, scouring protection, buoys) will provide additional (or new) settlement surface/habitat for benthic organisms and fishes (Langhamer et al., 2009), thus acting as an "artificial reef" (Langhamer et al., 2009); observations at artificial reefs and wind farms suggest that this effect generally results in positive impacts in terms of ecosystems and biodiversity (Petersen and Malm, 2006; Seaman, 2007; but see also Inger et al., 2009). In particular, the new settled communities may attract pelagic and nektonic organisms, forming a so-called "fish aggregation device" (Wilhelmsson et al., 2006). The resulting modification of pelagic and benthic habitats, communities and prey distributions may in turn enhance feeding opportunities for certain species of seabirds, cetaceans and pinnipeds (Wilhelmsson et al., 2010).

\section{Indicators implementation}

\subsection{Importance of environmental monitoring pro- grams}

The key environmental regulations of offshore MRE activities are similar in principles worldwide, as they derive 
from various international agreements and conventions. In particular, an Environmental Impact Assessment (EIA) is generally required prior to project consent, in order to ensure that the responsible authority makes a decision with the full knowledge of any significant effects (cumulative, positive and negative) on the environment. In this paper, Europe is taken as an example since it is where the offshore wind power sector is the most developed (EWEA, 2010; Tuebke and Hernandez Guevara, 2011; Madariaga et al., 2012).

The European Directive 2011/92/EU requires that Member States carry out an EIA for the consent of projects which are considered to have significant effects on the environment, including offshore wind project (e.g., CEFAS, 2004). For other MRE projects, the necessity to conduct an EIA is at the discretion of the Member States, even though in practice it is assumed that an EIA will be also required (Huertas-Olivares et al., 2007; Woolf, 2011; Margheritini et al., 2012). The findings of an EIA are reported in an Environmental Statement (ES), where the environmental factors that may be affected by the proposed project are described (e.g., Talisman, 2004), ideally, from construction to decommissioning. The ES also indicates the measures to implement for the mitigation of the potential negative impacts (see CEFAS, 2004). Moreover, an Environmental Management Plan (EMP) should be provided for the follow-up of effects that may threaten the environment (Huertas-Olivares et al., 2007).

The exact requested content of the EIA is highly variable in between Member States (and also sometimes in between projects within the same country) (Huertas-Olivares et al., 2007). A cumulative impact assessment should also be undertaken as part of the EIA process, but such assessments are rarely considered satisfactorily (Masden et al., 2010). In any case, with regards to the large knowledge gaps about the impacts of offshore MRE projects, it can be considered that the general policy is to "deploy and monitor", as opposed for example to the "precaution principle" which is applied to a large range of other activities and supported by EU regulation (Johnson et al., 2012). This is because the need to perform long-term research on environmental impacts is dominated by the imperative to develop marine energy which is driven by urgent political, economic and climate change considerations (Athanas and McCormick, 2013; SEL, 2010). Such a "deploy and monitor" policy requires the implementation of effective monitoring activities aimed at environmental protection and knowledge development. Therefore the EMP should be regarded as one of the most important outputs of the EIA, with the following general objectives:

- to provide feedback and early warning of potential environmental damages;

- to ensure that impacts do not exceed legal standards; and,
- to check the implementation of mitigation measures in the manner described in the ES report.

The use of environmental indicators to report the results of the EMP represents a great asset for the development of the incipient offshore MRE industry because indicators:

- conveniently convey information to government and industries about environmental effects (negative as well as positive);

- help to determine whether observed effects are acceptable or not through the upfront specification of thresholds and trigger levels;

- allow the effectiveness assessment of mitigation measures;

- allow comparisons with similar (MRE) projects and with other human activities; and,

- may be used as a tool for communication with other stakeholders, such as non-governmental organizations, the general public, etc.

The need to implement indicators for the evaluation of the environmental impacts of offshore windfarms has been recognized (Degraer and Brabant, 2009), but rarely put into practice. Some examples include the clicks' records of acoustic porpoise's detectors (T-Pods) which are used to define various indicators for density, abundance, activity, etc. (Rye et al., 2008; Lindeboom et al., 2011). At the Horns Rev 1 offshore windfarm, sand eels have been also used as indicators of the ecosystem health (Stenberg et al., 2011). However, existing indicators are generally site-specific and not explicitly linked to objectives and quantitative parameters or thresholds (e.g., Henriksen et al., 2003). With tighter environmental legislation that promotes the use of environmental indicators in marine areas, standardized monitoring protocols should be adopted to enhance their usage and utility (see Johnson, 2008; Degraer and Brabant, 2009). In that context, the use of tools such as the FoR approach may be useful for the definition and use of coherent sets of environmental indicators at offshore MRE projects. An additional benefit of these tools is the possibility to compare between different applications of the same indicator, in a process of gradual improvement. These approaches also help to evaluate if the cost of measuring the indicator is justified by the expected gain (increased level of environmental protection).

\subsection{The Frame of Reference approach}

The Frame of Reference (FoR) approach was developed to help researchers from different fields to use one method generically applicable to embed their results in a practical decision context (Van Koningsveld et al., 2003; Van Koningsveld and Mulder, 2004; Van Koningsveld et al., 2005a). 


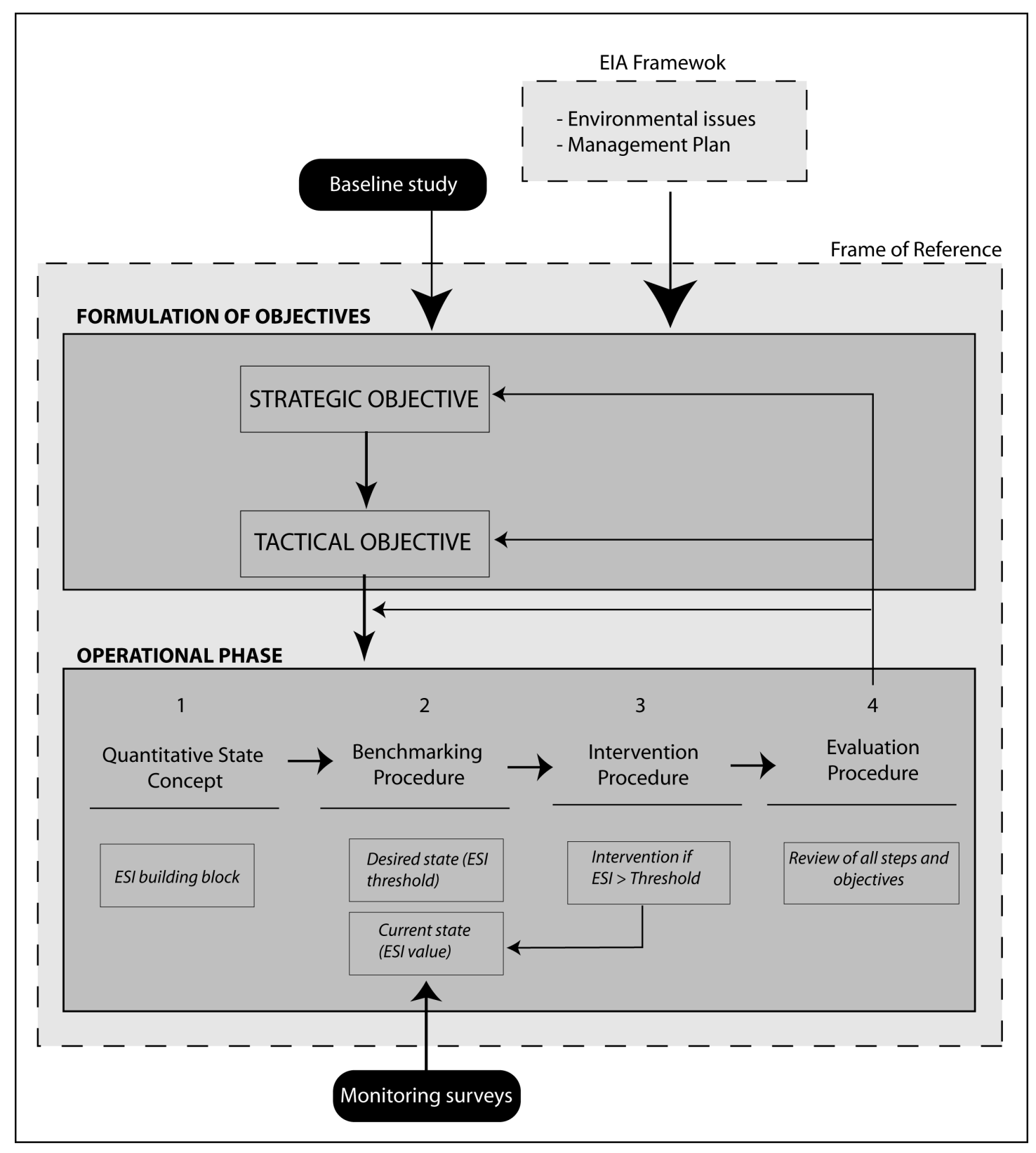

Figure 1: The Frame of Reference framework and application to offshore MRE projects (adapted from Van Koningsveld et al., 2007). The basic actions which are required at each steps of the operational phase are indicated in italics.

The approach is characterised by the definition of clear objectives at strategic and operational (or tactical) levels and an operational phase where indicators are defined to verify whether or not these objectives are met (Figure 1).

The FoR framework has been used so far for the implementation of coastal state indicators that help decision making with respect to the protection of eroding coasts, through enhanced communication between scientists and coastal managers (Van Koningsveld et al., 2007; Davidson et al., 2007; Ciavola et al., 2011; Marchand et al., 2011; De Vriend and Van Koningsveld, 2012). In fact, it has been used implicitly over the last decade in The Netherlands for the successful development and implementation of a coastal erosion policy (Van Koningsveld and Mulder, 2004; Van Koningsveld and Lescinski, 2007; Mulder et al., 2011).

The first step of the FoR approach is the formulation of "strategic objectives" based on the long-term vision about the desired status of the system (Figure 1). In a second step, the means of satisfying (at least partly) each strategic objective at the short-term are made explicit through the definition of one or several "operational objectives". Following Marchand et al. (2011) and Mulder et al. (2011), it might be more adequate to qualify these objectives as "tactical" -rather than "operational" - because this step implies a choice between distinct expedients to realise the corres- 
ponding strategic objective. The words and phrases used for the formulation of the objectives should be considered with extreme caution as they steer all consequent thinking; iteration is required in order to think through the process several times and ensure that the objectives are conceptualised adequately regarding the environmental issues which are at stake.

At the next level, an operational decision recipe consisting of four stages is applied in order to meet each of the predefined objectives:

\section{1. the Quantitative State Concept (QSC);}

\section{2. the Benchmarking procedure;}

\section{3. the Intervention procedure, and}

4. the Evaluation procedure.

The QSC defines for each tactical objective one or more quantifiable parameters that will be used in the decision making. This step is determinant regarding the actions to be implemented at the next stages, as it specifies the quantitative building block that is used to construct indicators (second stage), to establish the intervention procedure (third stage), and to help to assess whether or not the objectives are met (fourth stage).

Threshold values are attributed to the parameters defined at the QSC during the benchmarking procedure stage. These thresholds determine the desired state of the system, whilst the current state is established based on monitoring. The benchmarking procedure is therefore the indicator since it is at this stage that impacts are indicated through comparison of the current and desired state. In case of impact, the intervention procedure (third stage) prescribes the actions to implement for restoring the system toward the desired state. The current state is updated with (new) data from monitoring surveys, prior to another benchmarking procedure. It is important to design interventions as such that after implementation they influence the indicators status as desired. This may seem trivial, but it is not. Finally, the success of the actions undertaken at the three previous stages is assessed through an evaluation procedure, which determines whether the strategic and operational objectives are being met. At this stage, all the various steps of the framework should be subject to re-assessment. In particular, new parameters or threshold levels can be defined through new QSC and benchmarking procedures; both the strategic and operational objectives may also be modified if required. A FoR may also be discarded if it is found irrelevant or uneconomic for a given project or objective.

\section{Applicability of the Frame of Reference to off- shore MRE projects}

\subsection{General aspects}

The complexity of ecosystem processes and interactions in the offshore environment may result in a mismatch between scientists and decision makers' needs regarding the development of offshore MRE projects. Although originally developed for the implementation of coastal policy, the FoR approach could help through the construction of Environmental State Indicators (ESI) used to verify whether or not formulated objectives are met.

Obviously, the strategic objectives should derive from the key environmental issues identified through the EIA process. They might follow from (national or international) legislation, conventions or treaties. Strategic objectives might as well derive from binding conditions set by environmental agencies and local authorities for project consent, or by informal commitment of project managers. To ensure that all separate elements of the generally long lasting EIA process still fit together at the end of the process, a common framework for impacts classification, such as the stressor-receptor framework described in Section 2 (Boehlert and Gill, 2010), should be adopted during both the EIA and FoR procedures. This facilitates the communication between the various parties involved at any stage of the EMP. For example, stressor-receptor matrixes can be drawn to represent impacts severity, the temporal and spatial scales and uncertainties (see Polagye et al., 2011).

The operational phase should rely on the specific actions proposed in the EMP regarding the identification, followup and mitigation of impacts. At offshore wind farms (and presumably at any type of future MRE projects), the EMP commonly follows the Before-After Control-Impact (BACI) approach (Green, 1979), where the current state of the site is compared to previous and/or pristine environmental conditions known from the baseline study and from concurrent measurements at "reference areas". The definition of thresholds representing the "desired state" might be one of the most difficult tasks of impacts evaluation, since natural temporal and spatial variability of parameters must be considered. In some cases, indicator thresholds are fixed by legal requirements. In most cases, however, they must be established based on robust expertise together with a good knowledge of the natural environmental conditions at various spatial and temporal scales. Similarly, monitoring surveys alone might not be enough to embrace the natural variability (both spatial and temporal) of the measured parameters. The establishment of the current state may also be based on statistical and numerical models. Not only do these tools allow the interpretation of a limited number of measurements over broader areas and longer time-scales, but they can also be useful in defining environmental policies. 


\begin{tabular}{l||l|l|l|l} 
Receptor & Stressor & Effect & Environmental Issue & Description \\
\hline \hline Mammals & Sound & Avoidance & Porpoise protection & $\begin{array}{l}\text { Porpoises may escape the pro- } \\
\text { posed area due to the produc- } \\
\text { tion of sound }\end{array}$ \\
\hline Benthos & $\begin{array}{l}\text { Presence of } \\
\text { devices }\end{array}$ & Artificial reef & Habitat conservation & $\begin{array}{l}\text { The shell deposits of the newly } \\
\text { settled blue mussel may induce } \\
\text { a change from soft- to hard- } \\
\text { bottom substrates }\end{array}$ \\
\hline Birds & $\begin{array}{l}\text { Presence of } \\
\text { devices }\end{array}$ & Collision & $\begin{array}{l}\text { Common Eider ducks protec- } \\
\text { tion }\end{array}$ & $\begin{array}{l}\text { Migrating Eider ducks popula- } \\
\text { tion may suffer large loss from } \\
\text { collision with rotating blades }\end{array}$ \\
\hline Water quality & Chemical & Spilling & Water pollution & $\begin{array}{l}\text { The activity induces a risk of } \\
\text { oil spilling from device compon- } \\
\text { ents and vessels }\end{array}$
\end{tabular}

Table 2: Example of Environmental Issues identified during the EIA of a MRE project. The environmental concerns are explained in more detail in Subsection 4.2 .

about their flight patterns during periods of darkness and conditions of poor visibility such as fog or snow (Larsen and Guillemette, 2007). Under these bad visibility conditions, the probability of collision with wind turbines may be significantly enhanced, especially if birds are attracted by illuminated turbines (Fox et al., 2006). Eider ducks are protected under the EU Bird Directive.

- Water quality: The water quality may be affected as a result of oil spilling from components (e.g., gear boxes, hydraulic pumps) of MRE devices, and also from vessels and helicopters supporting the activity.

Regarding harbour porpoise protection against underwater sound, the long-term strategic objective of the FoR could be 'to preserve the regional population given the planned activity' (Table 3). Studies have shown that wind farm related sound, for example, has the potential to affect the behaviour and physiology of harbour porpoises at considerable distances. Physiological effects include Temporary and Permanent Hearing Threshold Shifts and more severe injuries up to death, depending of the distance of the individual to the source. Hence, one tactical objective could be that 'no porpoise should suffer from sound related to the activity' (Table 3). More specifically this objective could be achieved by either reducing the sound at the source or by physically keeping the porpoise away from areas where sound levels are potentially harmful. The underwater sound hazard is greatest during the construction phase, when porpoises are present in the area. Past experience has shown that porpoises avoid areas where piling activities take place; lethal hearing injuries may occur if they are located too close to the source when hammering starts. In this example we will focus on keeping the porpoises at a safe distance from the sound source. Recent studies have indicated that during piling, severe injuries are estimated to occur in a radius of $1.8 \mathrm{~km}$ from the source (Thomsen et al., 2006). The ESI in this case might be derived from the observation of the "number of 


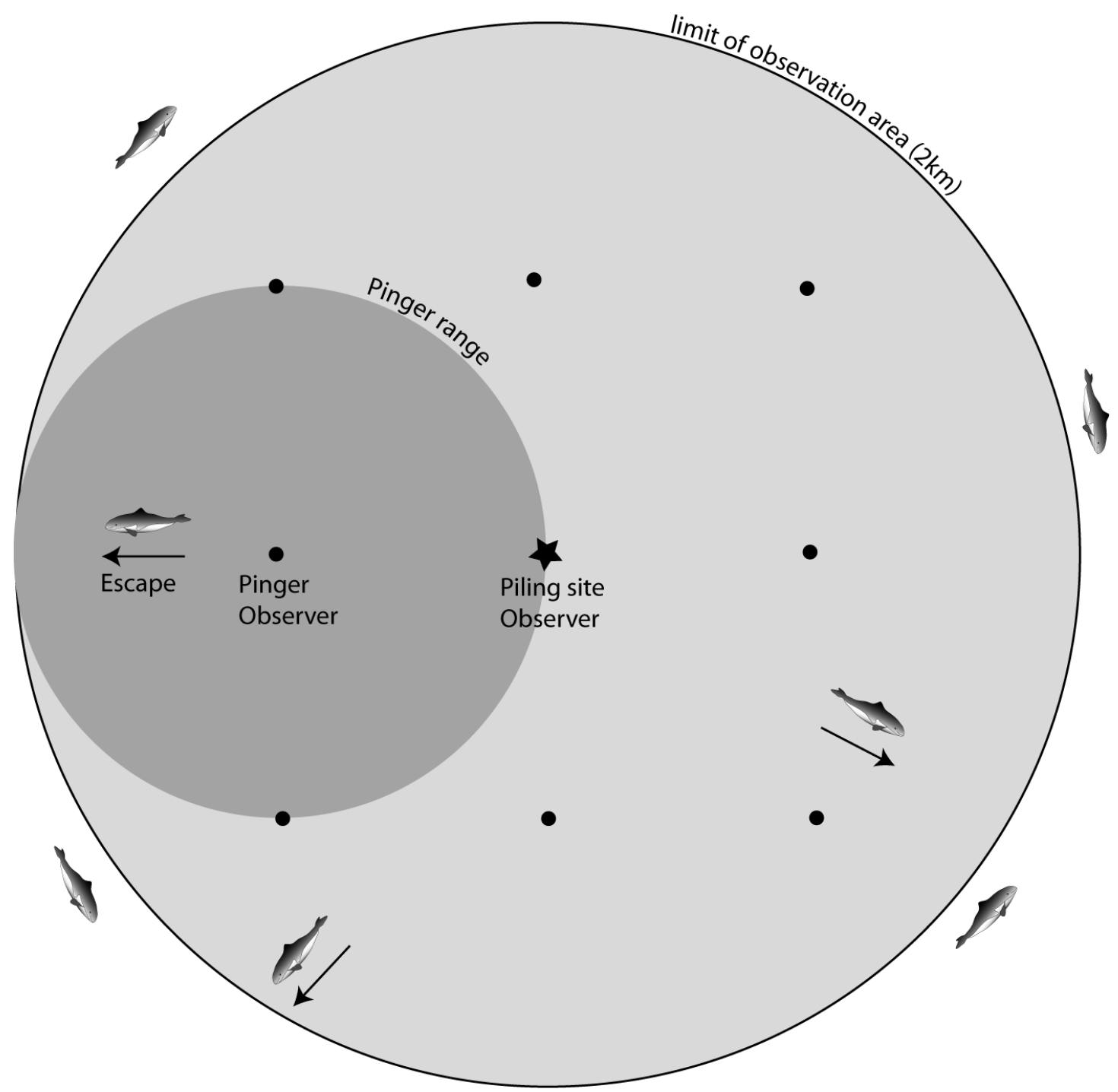

Figure 2: Example of field set up for an operational phase designed to scare porpoises during piling (see tactical objective). Eight pingers (dots) with $1 \mathrm{~km}$ range each (see the dark grey area, represented for one pinger only) are used to scare porpoises before piling starts to allow them to escape the area. Marine mammal observers, one at each pinger location plus one at the piling site, establish the current state (benchmarking), by checking for the presence of porpoise in the $2 \mathrm{~km}$ radius area of potential injuries by sound (light grey area). Piling is allowed to start if no porpoise is observed in this area during the preceding $2 \mathrm{hr}$ (ESI).

individuals within $2 \mathrm{~km}$ from the source, after the deployment of acoustic harassment (or scaring) devices, during a certain time (e.g., $2 h r$ ) prior to conduct the piling operations' (QSC, Table 3; Figure 2). Several devices might be necessary, depending on their range of effectiveness (e.g., Cox et al., 2001; Culik et al., 2001). The desired state is the absence of individual within the $2 \mathrm{~km}$ radius during this time interval (Table 3). The current state could be established based on marine mammal observers deployed in order to visually cover the total area of restriction (Figure 2; Table 3). If no individual is observed, piling can start without concerns for porpoises. Otherwise, operations should be postponed until reaching the desired state; the use of additional or other types of repelling devices might be necessary (Intervention procedure, Table 3). Evaluating the proposed procedure it seems likely that this FoR will contribute to its strategic objective. The tactical objective is vulnerable to marine mammals observers missing porpoises that still are present despite the period of harassment. Put in practice procedures should be optimized to minimize this risk.

The proposed project will undoubtedly induce local physical changes of habitat (if only for the introduction of hard structures in the water). The development of organisms such as mussels on the structures may create locally "hot spots" of biological activity (e.g., Norling and Kautsky, 2008) that could be beneficial to the ecosystem (including the shoal benthic community). Thus, one strategic objective could be to enhance biodiversity and productivity, providing there is no negative impact -for example due to 


\begin{tabular}{|c|c|c|c|c|c|c|}
\hline $\begin{array}{l}\text { Environmental } \\
\text { issue }\end{array}$ & $\begin{array}{l}\text { Strategic } \\
\text { Objective }\end{array}$ & $\begin{array}{l}\text { Tactical } \\
\text { Objective }\end{array}$ & $\begin{array}{l}\text { Quantitative } \\
\text { State Concept }\end{array}$ & $\begin{array}{l}\text { Benchmarking } \\
\text { Desired State }\end{array}$ & $\begin{array}{l}\text { Benchmarking } \\
\text { Current State }\end{array}$ & $\begin{array}{l}\text { Intervention } \\
\text { Procedure }\end{array}$ \\
\hline $\begin{array}{l}\text { Harbour por- } \\
\text { poise protec- } \\
\text { tion }\end{array}$ & $\begin{array}{l}\text { To preserve the } \\
\text { regional popu- } \\
\text { lation given the } \\
\text { planned activ- } \\
\text { ity }\end{array}$ & $\begin{array}{lr}\text { No porpoise } \\
\text { should } & \text { suffer } \\
\text { from sound } \\
\text { related to the } \\
\text { activity }\end{array}$ & $\begin{array}{l}\text { Number of } \\
\text { individuals } \\
\text { observed in } \\
\text { a radius of } 2 \\
\mathrm{~km} \text { from the } \\
\text { source, during } \\
2 \mathrm{hr} \text { of acoustic } \\
\text { harassment, } \\
\text { prior to the } \\
\text { start of piling }\end{array}$ & $\begin{array}{l}\text { No individual } \\
\text { in the } 2 \mathrm{~km} \\
\text { radius area, } \\
\text { during } 2 \mathrm{hr} \\
\text { prior to piling } \\
\text { starts }\end{array}$ & $\begin{array}{l}\text { Marine Mam- } \\
\text { mals Observers } \\
\text { distributed in } \\
\text { order to cover } \\
\text { by eye the } 2 \\
k m \text { radius area }\end{array}$ & $\begin{array}{l}\text { Do not start } \\
\text { piling, increase } \\
\text { the number } \\
\text { of repelling } \\
\text { devices }\end{array}$ \\
\hline $\begin{array}{l}\text { Conservation of } \\
\text { sandy habitat }\end{array}$ & $\begin{array}{lr}\text { To maintain } \\
\text { the existing } \\
\text { sandy habitat } \\
\text { within the } \\
\text { project area }\end{array}$ & $\begin{array}{l}\text { Shell } \begin{array}{r}\text { beds } \\
\text { should }\end{array} \text { not } \\
\text { cover }>25 \% \\
\text { of the project } \\
\text { area during } \\
\text { operations }\end{array}$ & $\begin{array}{l}\begin{array}{l}\text { Relative } \\
\text { centage }\end{array} \begin{array}{r}\text { per- } \\
\text { of }\end{array} \\
\text { surface area } \\
\text { covered by } \\
\text { shells in a } \\
\text { random subset } \\
\text { area being } 10 \% \\
\text { of the total } \\
\text { project area }\end{array}$ & $\begin{array}{l}\text { Less than } 25 \% \\
\text { of the sandy } \\
\text { surface within } \\
\text { the subset area } \\
\text { covered }\end{array}$ & $\begin{array}{l}\text { Ground- } \\
\text { truthed side- } \\
\text { scan sonar data } \\
\text { over the entire } \\
\text { subset area }\end{array}$ & $\begin{array}{l}\text { Restore habitat } \\
\text { (environmental } \\
\text { dredging) } \\
\text { along corridors } \\
\text { in between the } \\
\text { devices within } \\
\text { the entire } \\
\text { project area }\end{array}$ \\
\hline $\begin{array}{l}\text { Common Eider } \\
\text { duck protection }\end{array}$ & $\begin{array}{l}\text { To preserve the } \\
\text { population of } \\
\text { Common Eider } \\
\text { Duck passing } \\
\text { over the region }\end{array}$ & $\begin{array}{l}\text { The project } \\
\text { activities } \\
\text { should not } \\
\text { increase the } \\
\text { population } \\
\text { mortality rate }\end{array}$ & $\begin{array}{l}\text { Percentage of } \\
\text { duck popula- } \\
\text { tion at risk of } \\
\text { collision with } \\
\text { the structures }\end{array}$ & $\begin{array}{l}\text { No more than } \\
5 \% \text { of the } \\
\text { population } \\
\text { predicted to } \\
\text { collide }\end{array}$ & $\begin{array}{l}\text { Predictions } \\
\text { from stochastic } \\
\text { model at } 95 \% \\
\text { confidence } \\
\text { interval }\end{array}$ & Stop turbines \\
\hline $\begin{array}{l}\text { Water pollu- } \\
\text { tion by oil }\end{array}$ & $\begin{array}{l}\text { To preserve fa- } \\
\text { vourable water } \\
\text { quality for local } \\
\text { flora and fauna }\end{array}$ & $\begin{array}{l}\text { Timely proact- } \\
\text { ive mainten- } \\
\text { ance of oper- } \\
\text { ating devices } \\
\text { containing oil }\end{array}$ & $\begin{array}{l}\text { Timely re- } \\
\text { placement of } \\
\text { components } \\
\text { containing } \\
\text { oil, at time } \\
\text { defined by } \\
\text { the preventive } \\
\text { maintenance } \\
\text { strategy }\end{array}$ & $\begin{array}{l}\text { Timely sub- } \\
\text { stitution of } \\
\text { components } \\
\text { and visual } \\
\text { inspections } \\
\text { during main- } \\
\text { tenance }\end{array}$ & $\begin{array}{l}\text { Actual sub- } \\
\text { stitution of } \\
\text { components } \\
\text { and visual } \\
\text { inspections } \\
\text { during main- } \\
\text { tenance }\end{array}$ & $\begin{array}{l}\text { Substitution of } \\
\text { defective com- } \\
\text { ponents and } \\
\text { re-evaluation of } \\
\text { the mainten- } \\
\text { ance strategy } \\
\text { for the relevant } \\
\text { component }\end{array}$ \\
\hline
\end{tabular}

Table 3: Examples of application of the FoR approach to MRE projects. The gray column (QSC) corresponds to the quantitative building block that is used for the construction of the indicator at the benchmarking procedure stage. For explanations, see text.

greater predation- on the shoal benthic community (another FoR may be defined to tackle this latter issue); this objective could be achieved through the selection of underwater structures designed to favour the colonisation of selected species (see Martins et al., 2010; De Vriend and Van Koningsveld, 2012; De Vriend et al., 2014). Another (more defensive) approach, taken as example here, could be to 'maintain the existing sandy habitat within the project area' (Strategic objective, Table 3). This approach supposes that it has been previously evidenced that reduction of this habitat induces negative impacts (at present, this effect is generally not a major concern, but it could become substantial in the case of farms with several hundreds of devices operating for decades). It is technically difficult and costly to inhibit the colonisation of organisms on newly introduced material. Thus, the tactical objective could be that 'shell beds should not cover more than $25 \%$ of the project area during operation' (Table 3 ). The QSC stage may define the parameter to quantify the ex- tension of shell beds as the 'relative percentage of surface area which is covered by shell deposits within a subset region (selected randomly) corresponding to $10 \%$ in surface area of the proposed project' (Table 3). This requires that the distinction between sandy and mussel bed habitats is clearly defined at the benchmarking procedure, as it depends on the method used to establish the current state. For example, if mechanical sediment sampling is involved, the classification of sand mixed with mussels as "sandy" or "shell" habitats requires the definition of limit values, e.g., in terms of relative weight of shells or grain size parameters. Our example contemplates (ground-truthed) side-scan sonar images since they generally allow a clear distinction of hard and soft beds based on their tonal contrast (Table 3). The desired state corresponds to 'less than $25 \%$ of shell beds within the subset area'. More complex proactive approaches could rely on the outputs from models of mussels growth and deposition (e.g., Maar et al., 2009). The intervention procedure could encompass envir- 


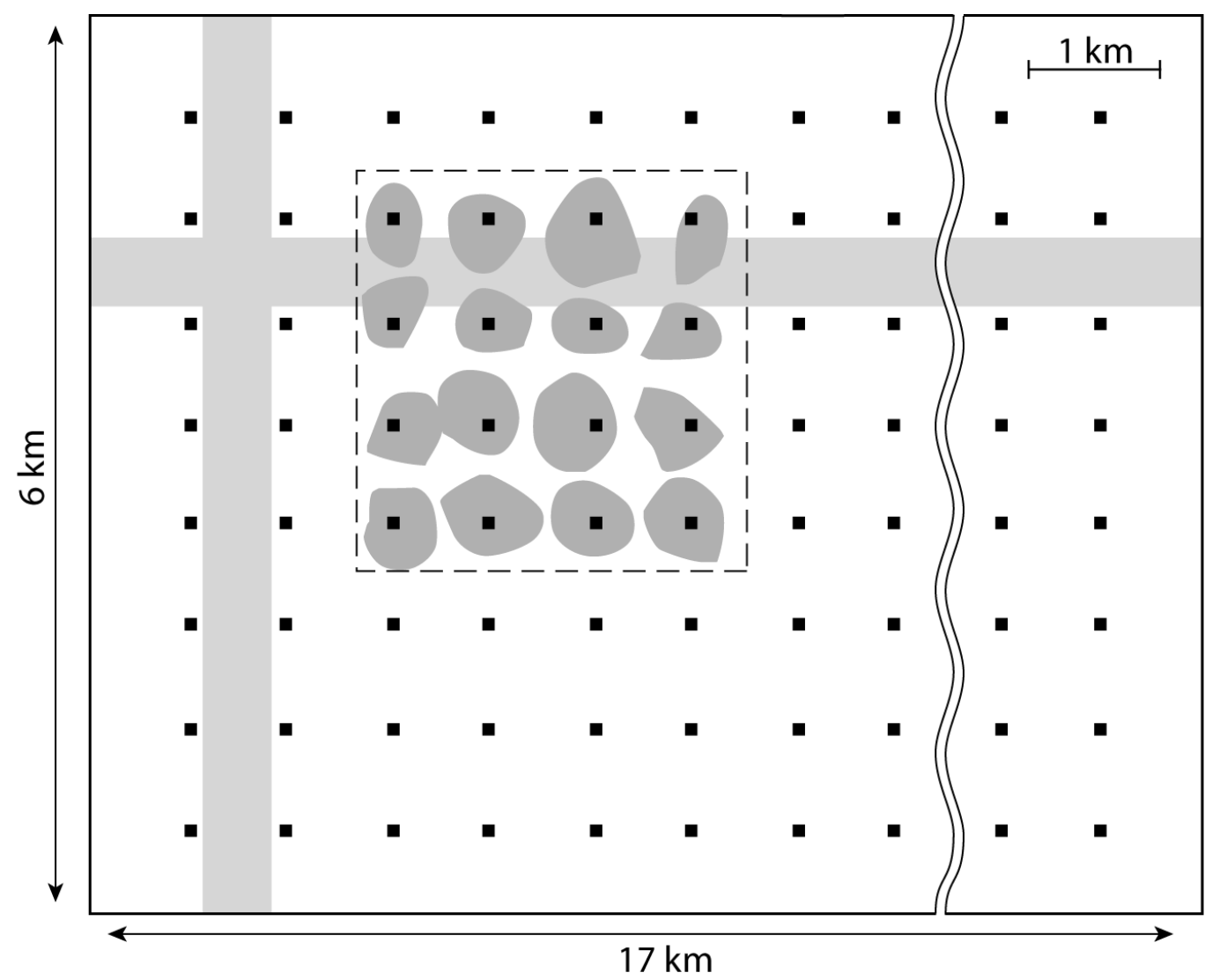

Figure 3: Implementation of the operational phase designed to control the development of mussel beds within the project area (Tactical objective). The total area (plan view) is $100 \mathrm{~km}^{2}$ and includes $176 \mathrm{MRE}$ devices (dots). Ground-truthed side-scan sonar surveys are conducted in a $10 \mathrm{~km}^{2}$ area (dashed line) to distinguish sandy bed (white) from shell beds (dark grey). If shell beds represents $>25 \%$ of the survey area, environmental dredging is performed along parallel corridors over the entire project area to remove the mussel layer (examples of these corridors are shown in light grey).

onmental dredging guided by video to remove the excess of deposited layer of material and restore the original habitat along corridors in between the devices (Table 3; Figure 3). Such a mitigation option requires strong awareness regarding the financial implication of its implementation. For example, economic feasibility will be dependent of the required dredging frequency (every year? every ten years?), estimated based on modelling tools (e.g., coupled hydrodynamic and mussel deposit models). Careful economic assessment whether the cost associated with a measure can be justified by the environmental gain is crucially important. In the end it might be concluded that environmental dredging is too expensive to be implemented, in which case more reachable objectives must be set at the start of the FoR process. Another issue could be that the proposed intervention (environmental dredging) itself is hampering the strategic objective (preservation of the existing sandy habitat). Such potential points of contention highlights the importance of adopting an iterative approach when formulating the strategic and operational objectives.

Any impact of the project on migrating Common Eider ducks must be analysed at a population level. As a strategic objective, the project activities should 'preserve the population of Common Eider ducks passing over the region' (Table 3), where the extension of the "region" is clearly defined. One way of meeting this objective could be 'to prevent any increase of their mortality rate related to the project activities' (Tactical objective, Table 3). At the QSC stage, this objective may lead to the development of a parameter representing the percentage of the duck population risking collision with the structures. For selected periods, the current state can be predicted with a level of certainty (for example, 95\% confidence interval) based on stochastic models built from compilations of observations (Figure 4; Table 3). In particular, reliable model predictions require estimates of the number of individual Eider duck collisions within the project area and of their fluxes throughout the project area (e.g., Band, 2000; Petersen et al., 2006; Troost, 2008). Collision estimates can be obtained using non-contact sensors (e.g., acoustic sensors, microphones) deployed on a number of turbines, especially during periods of heavy migration (spring and autumn). Likewise, surveillance radars are useful to measure the volume of bird movement and to track their altitude and trajectories through the area (visual observations are also necessary to calibrate the radar signal for species distinc- 


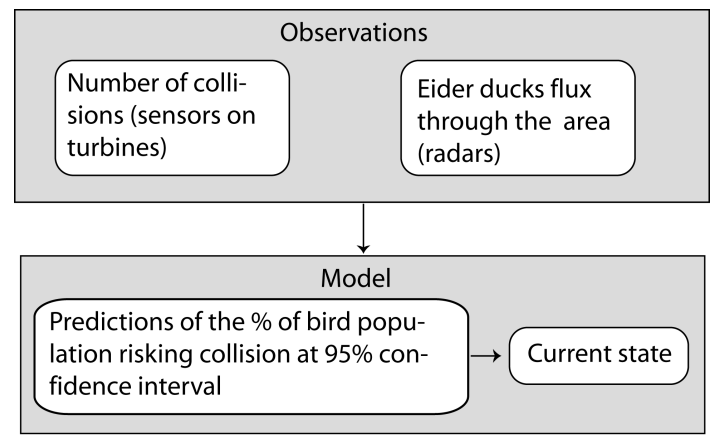

Figure 4: Illustration of the definition of the current state for selected periods of Eider duck migration. Observations (radar and collision monitoring data) are compiled to build a stochastic model. The current state is derived from model prediction of the percentage of bird risking collision with the turbines at a $95 \%$ confidence interval.

tion). The desired state (Table 3), for example 'no more than $5 \%$ of the population predicted to collide', should be fixed considering the effects of the increased mortality on the population over longer time periods (Fox et al., 2006). As a proactive intervention measure, it could be possible to shut down turbines during the periods when the indicator threshold is exceeded (Table 3).

With respect to water pollution, one obvious strategic objective is 'to preserve favourable water quality for local flora and fauna' (Table 3). One of the various tactics that can contribute to meet this objective is to ensure a 'timely proactive maintenance of the operating devices containing oil', e.g., gear boxes, hoses, in order to prevent oil leaks from happening (Table 3). In this case, the QSC can make use of the maintenance task which is generally established for each component (based on reliability figures like failure rate) for preventive maintenance throughout the duration of the project (Table 3). The comparison between the desired and current states is then performed by comparing the planned replacement of components with the actual recorded replacement. In addition to the preventive replacement of device components, the mitigation procedure may request to revise the maintenance strategy (e.g., frequency) in order to avoid future oil leaking from the relevant component (see the example in Figure 5). Compared to the harbour porpoise example this FoR is likely to achieve its tactical objective. The strategic objective, however, remains vulnerable as other potential causes for leakage are not addressed. This issue should be addressed with the definition of additional tactical objectives.

\section{Conclusions and recommendations}

It is in the interest of the incipient offshore MRE industry to carefully address the environmental impacts induced by large-scale projects. This task is presently difficult to achieve satisfactorily due to large knowledge gaps about

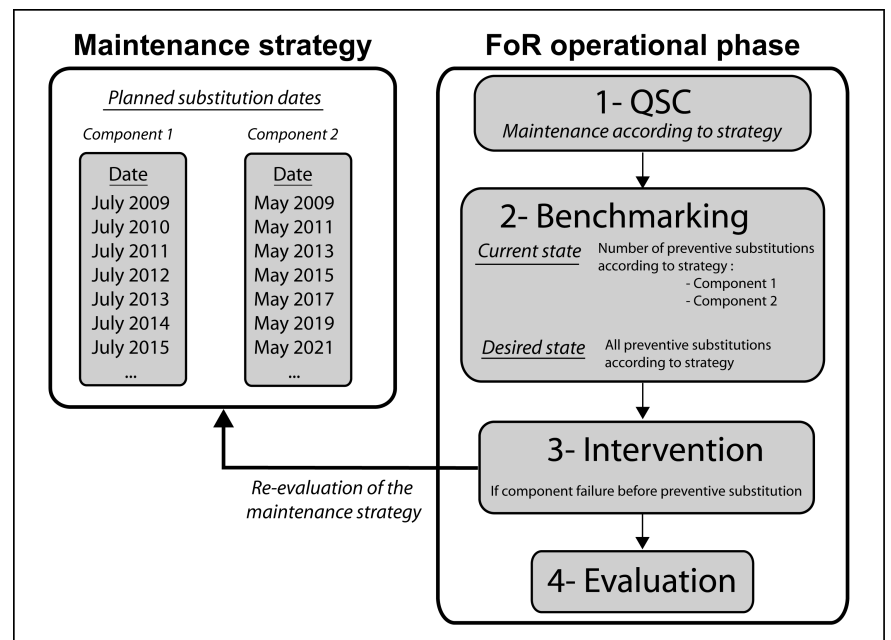

Figure 5: Example of the operational phase of a FoR (right panel) designed for a proactive maintenance of components containing oil (tactical objective). The maintenance strategy (left panel) defines the dates of component substitution (for simplicity, two components are considered). The QSC (Stage 1) is based on the maintenance strategy to indicate impacts during the benchmarking procedure (Stage 2). If failure occurs before the planned substitution of the components, the intervention procedure (Stage 3) requires a revision of the maintenance strategy.

impacts. Thorough long-term (years) EMPs should be implemented in order to enhance scientific knowledge regarding impacts. The implementation of environmental indicators within these programs is recommended as they generally describe in a convenient (simplified) manner the status of (complex) systems and thus may facilitate management decisions.

For the implementation of indicators within EMPs, the FoR approach is advocated over other frameworks due to its prescriptive nature. The FoR provides clear guidance for the selection of indicators that are linked directly to specific management issues. This framework also makes sure that predefined intervention procedures will be implemented if mitigation or remediation actions are required.

The examples presented in this contribution describe the use of FoR as a remediation tool. However, the most effective options to mitigate environmental impacts are generally available during the design phase of the project, i.e., during the selection of the site, of the technology to be used, and of the project layout. It is recommended to implement the FoR approach at various phases of the lifecycle of a project.

The development of a FoR framework is recommended for each of the potential environmental issues. The possible interaction between management issues from different FoRs must be addressed. In particular, future research should seek to optimise the collaborative effort not only between scientists of distinct disciplines, but also between all the parties at stake (non-governmental organ- 
isations, nature conservation organisations, stakeholders, managers, policy makers). Furthermore, the development of several FoRs may require the integration of various time and space scales. It is therefore also recommended to investigate the articulation between the distinct management scales (see Mulder et al., 2006).

The occurrence of many environmental issues may also lead to the development of FoRs with conflicting objectives. In such a case, optimising a particular ESI may be detrimental to other objectives. Hence, it would be helpful to have some methods that help to decide what the best option is. Some tools should be developed to rank or prioritise the FoR with conflicting objectives.

Furthermore, it is important that an open policy regarding data access is implemented at a national, European and international level (e.g., the "OpenEarth" approach; Van Koningsveld et al., 2005b; Baart et al., 2012; De Boer et al., 2012; Van Koningsveld et al., 2013). Such a policy would be highly beneficial for research about environmental impacts, and for the industry to establish costefficient EMPs while demonstrating a strong commitment toward environmental protection.

Management decisions may have strong ecological influences and substantial financial implications. This fact often leads to reluctance to embrace new, unproven methodologies. It is therefore essential to rigorously test the FoR approach against real cases in order to firmly demonstrate how it can improve the management of specific environmental issues. At last, there should be a strong awareness of the potential financial implications of the managing decisions proposed in the various indicator schemes. As a final recommendation, any set of indicators should be always, as much as possible, scrutinized and tested for practical applicability in relation to the overall protection objective.

\section{Acknowledgements}

EG, ÓF and CC acknowledge support from the MARINA (Marine Renewable Integrated Application) Platform project, a Collaborative Project of the 7th Framework Programme (Grant agreement number: 241402).

The work by MvK was executed as part of the Marine Ingenuity program that has been established by Van Oord to stimulate innovation and knowledge transfer.

\section{References}

Andrade, H., Renaud, P.E., 2011. Polychaete/amphipod ratio as an indicator of environmental impact related to offshore oil and gas production along the norwegian continental shelf. Marine Pollution Bulletin 62(12), 2836-2844. doi:10.1016/j.marpolbul. 2011. 08.032 .
Athanas, A.K., McCormick, N., 2013. Clean energy that safeguards ecosystems and livelihoods: Integrated assessments to unleash full sustainable potential for renewable energy. Renewable Energy 49, 25-28. doi:10.1016/j.renene.2012.01.073.

Baart, F., De Boer, G., De Haas, W., Donchyts, G., Philippart, M., Van Koningsveld, M., Plieger, M., 2012. A comparison between WCS and OPeNDAP for making model results and data products available through the internet. Transactions in GIS 16(2), 249265. doi:10.1111/j.1467-9671.2012.01312.x.

Bald, J., Del Campo, A., Franco, J., Galparsoro, I., González, M., Liria, P., Muxika, I., Rubio, A., Solaun, O., Uriarte, A., Comesaña, M., Cacabelos, A., Fernández, R., Méndez, G., Prada, D., Zubiate, L., 2010. Protocol to develop an environmental impact study of wave energy converters. Revista de Investigación Marina 17(5), 62-138.

Band, W., 2000. Windfarms and birds: Calculating a theoretical collision risk assuming no avoiding action. Technical Report. Scottish Natural Heritage (SNH). URL: http://www.snh.gov.uk/docs/ C205425.pdf. p. 10 .

Bedard, R., Jacobson, P.T., Previsic, M., Musial, W., Varley, R., 2010. An overview of ocean renewable energy technologies. The Oceanography Society 23(2), 22-31. URL: http://www.tos.org/ oceanography/archive/23-2_bedard.pdf.

Boehlert, G.W., Gill, A.B., 2010. Environmental and ecological effects of ocean renewable energy development: a current synthesis. The Oceanography Society 23(2), 68-81. URL: http://ir.library.oregonstate.edu/xmlui/ bitstream/handle/1957/16152/23-2_boehlert_hi.pdf

Borja, A., Galparsoro, I., Solaun, O., Muxika, I., Tello, E.M., Uriarte, A., Valencia, V., 2006. The European Water Framework Directive and the DPSIR, a methodological approach to assess the risk of failing to achieve good ecological status. Estuarine, Coastal and Shelf Science 66(1-2), 84-96. doi:10.1016/j.ecss. 2005.07.021.

Brostrom, G., 2008. On the influence of large wind farms on the upper ocean circulation. Journal of Marine Systems 74(1-2), 585591. doi:10.1016/j.jmarsys. 2008.05.001.

$\mathrm{BSH}, 2007$. Investigation of the Impacts of Offshore Wind Turbines on the Marine Environment (StUK 3). Technical Report BSHNr. 7003. Bundesamt f ur Seeschiffahrt und Hydrographie (BSH). Hamburg and Rostock. URL: http://www.bsh.de/en/Products/ Books/Other_publications/Stuk-eng.pdf. p. 57.

Bulleri, F., Airoldi, L., 2005. Artificial marine structures facilitate the spread of a non-indigenous green alga, Codium fragile ssp. tomentosoides, in the north Adriatic Sea. Journal of Applied Ecology 42(6), 1063-1072. doi:10.1111/j.1365-2664.2005.01096.x.

Butterfield, S., Musial, W., Jonkman, J., 2007. Engineering Challenges for Floating Offshore Wind Turbines, Offshore wind conference. Technical Report. National Renewable Energy Laboratory. Copenhagen, Denmark. P. 13.

CEFAS, 2004. Offshore Wind Farms: Guidance Note for Environmental Impact Assessment in Respect of FEPA and CPA Requirements. Technical Report. Marine Consents and Environment Unit (MCEU). P. 48.

Ciavola, P., Ferreira, O., Haerens, P., Van Koningsveld, M., Armaroli, C., 2011. Storm impacts along European coastlines. Part 2: lessons learned from the MICORE project. Environmental Science \& Policy 14(7), 924-933. doi:10.1016/j.envsci.2011.05.009.

CMACS, 2003. A baseline assessment of electromagnetic fields generated by offshore windfarm cables. Technical Report. Centre for Marine \& Coastal Studies CMACS. COWRIE Report EMF-01200266 , p. 71.

Cox, T.M., Read, A.J., Solow, A., Tregenza, N., 2001. Will harbour porpoises (Phocoena phocoena) habituate to pingers? Journal of Cetacean Research and Management 3(1), 81-86.

Culik, B.M., Koschinski, S., Tregenza, N., Ellis, G.M., 2001. Reactions of harbour porpoises Phocoena phocoena and herring Clupea harengus to acoustic alarms. Marine Ecology Progress Series 211, 255-260.

Danish Energy Authority, 2009. Offshore Wind Farms and the Environment Danish Experience from Horns Rev and Nysted. Tech- 

the communication agency Operate A/S. P. 41.

Davidson, M.A., van Koningsveld, M., de Kruif, A.C., Rawson, J. Holman, R.A., Lamberti, A., Medina, R., Kroon, A., Aarninkhof, S.G.J., 2007. The CoastView project: developing videoderived coastal state indicators in support of coastal zone management. Coastal Engineering 54(6-7), 463-475. doi:10.1016/j . coastaleng.2007.01.007.

Davies, J., Baxter, J., Bradley, M., Connor, D., Khan, J., Murray, E., Sanderson, W., Turnbull, C., Vincent, M., 2001. Marine Monitoring Handbook. Technical Report. Joint Nature Conservation Committee. URL: http://jncc.defra.gov.uk/PDF/ MMH-mmh_0601.pdf. p. 405.

De Boer, G.J., Baart, F., Bruens, A., Damsma, T., Van Geer, P., Grasmeijer, B., Den Heijer, K., Van Koningsveld, M., 2012. Openearth: using Google Earth as outreach for NCK's data, in: Kranenburg, W.M., Horstman, E.M., Wijnberg, K.M. (Eds.), NCKdays 2012 : Crossing borders in coastal research : jubilee conference proceedings, University of Twente, Department of Water Engineering \& Management, Enschede, The Netherlands. pp. 97103. doi:10.3990/2.177.

De Vriend, H.J., Van Koningsveld, M., 2012. Building with Nature: Thinking, acting and interacting differently. EcoShape, Building with Nature, Dordrecht, the Netherlands. URL: http:// ecoshape.nl/files/paginas/ECOSHAPE_BwN_WEB.pdf.

De Vriend, H.J., Van Koningsveld, M., Aarninkhof, S.G.J., 2014 'Building with nature': the new Dutch approach to coastal and river works. Proceedings of the ICE - Civil Engineering 167(1), 18-24. doi:10.1680/cien.13.00003.

Defew, E., Wood, C., Bates, R., Wilson, L., Wilson, J., 2012. An assessment of the potential impact of no-take zones upon benthic habitats: a case study from SE Scotland. Technical Report. The Crown Estate. P. 37.

Degraer, S., Brabant, R., 2009. Offshore wind farms in the Belgian part of the North Sea: State of the art after two years of environmental monitoring. Technical Report. Royal Belgian Institute for Natural Sciences, Management Unit of the North Sea Mathematical Models, Marine ecosystem management unit. P. 287.

Desholm, M., 2009. Avian sensitivity to mortality: Prioritising migratory bird species for assessment at proposed wind farms. Journal of Environmental Management 90(8), 2672-2679. doi:10. 1016/j.jenvman.2009.02.005.

Drew, B., Plummer, A.R., Sahinkaya, M.N., 2009. A review of wave energy converter technology. Journal of Power and Energy 223(8), 887-902. doi:10.1243/09576509JPE782.

Dubois, S., Gelpi, C., Condrey, R., Grippo, M., Fleeger, J., 2009. Diversity and composition of macrobenthic community associated with sandy shoals of the Louisiana continental shelf. Biodiversity and Conservation 18(14), 3759-3784. doi:10.1007/ s10531-009-9678-3.

Elliott, M., 2002. The role of the DPSIR approach and conceptual models in marine environmental management: an example for offshore wind power. Marine Pollution Bulletin 44(6), iii-vii. doi:10.1016/S0025-326X (02) 00146-7.

Evans, P.G.H., 2008. European cetacean societys 21st annual conference, in: Offshore wind farmsand marine mammals: impacts \& methodologies for assessing impacts, San Sebastian, Spain. p. p. 70 .

EWEA, 2010. Annual Report 2009. Technical Report. European Wind Energy Association. P. 40.

EWEA, 2012. The European offshore wind industry key 2011 trends and statistics. Technical Report. European Wind Energy Association. P. 23

Fayram, A.H., De Risi, A., 2007. The potential compatibility of offshore wind power and fisheries: An example using bluefin tuna in the Adriatic Sea. Ocean \& Coastal Management 50(8), 597-605. doi:10.1016/j.ocecoaman.2007.05.004.

Fox, A.D., Desholm, M., Kahlert, J., Christensen, T.K., Petersen, I.K., 2006. Information needs to support environmental impact assessment of the effects of european marine offshore wind farms on birds. Ibis 148(S1), 129-144. doi:10.1111/j.1474-919X. 2006. 00510.x.

Gabrielsen, P., Bosch, P., 2003. Environmental Indicators: Typology and Use in Reporting. Technical Report. European Environment Agency (EEA). P. 20, EEA internal working paper

Gill, A., 2005. Offshore renewable energy: Ecological implications of generating electricity in the coastal zone. Journal of Applied Ecology 42(4), 605-615. doi:10.1111/j.1365-2664.2005.01060.x.

Gill, A.B., Gloyne-Phillips, I., Neal, K.J., Kimber, J.A., 2005. The potential effects of electromagnetic fields generated by sub-sea power cables associated with offshore wind farm developments on electrically and magnetically sensitive marine organisms, Electromagnetic fields review. Technical Report. Cowrie. P. 128.

Gill, A.B., Huang, Y., Gloyne-Philips, I., Metcalfe, J., Quayle, V., Spencer, J., Wearmouth, V., 2009. EMF-sensitive fish response to EM emissions from sub-sea electricity cables of the type used by the offshore renewable energy industry, Electromagnetic Fields (EMF) Phase. Technical Report. Cowrie. P. 128.

Glasby, T., Connell, S andHolloway, M., Hewitt, C., 2007. Nonindigenous biota on artificial structures: could habitat creation facilitate biological invasions? Marine Biology 151(3), 887-895. doi:10.1007/s00227-006-0552-5.

Green, R.H., 1979. Sampling design and statistical methods for environmental biologists. New York, John Wiley and Sons.

Gubbay, S., 2004. A review of marine environmental indicators reporting on biodiversity aspects of ecosystem health. Technical Report. The Royal Society for the Protection of Birds. Sandy, UK. URL: http://www.rspb.org.uk/Images/Indicators_ tcm9-132910.pdf. p. 78.

Hastings, M.C., Popper, A.N., 2005. Effects of Sound on Fish. Jones and Stokes.

Heink, U., Kowarik, I., 2010. What are indicators? On the definition of indicators in ecology and environmental planning. Ecological Indicators 10(3), 584-593. doi:10.1016/j.ecolind.2009.09.009.

Henriksen, O.D., Teilmann, J., Cartensen, J., 2003. Effects of the Nysted Offshore Wind Farm construction on harbour porpoises. Technical Report. Technical Report of the National Environment Research Institute. Ministry of the Environment, Denmark. P. 45.

Huertas-Olivares, C., Russell, I., Patricio, S., Neumann, F., Sarmento, A., 2007. Comparative study of baseline environmental studies in offshore renewable energies, Seventeenth International Offshore and Polar Engineering Conference. Technical Report. The International Society of Offshore and Polar Engineers (ISOPE). Lisbon, Portugal. Pp. 467-474.

Inger, R., Attrill, M.J., Bearhop, S., Broderick, A.C., Grecian, W.J., Hodgson, D.J., Mills, C., Sheehan, E., Votier, S.C., Witt, M.J., Godley, B.J., 2009. Marine renewable energy: potential benefits to biodiversity? An urgent call for research. Journal of applied ecology 46(6), 1145-1153. doi:10.1111/j.1365-2664.2009.01697.

Johnson, D., 2008. Environmental indicators: their utility in meeting the OSPAR Conventions regulatory needs. ICES Journal of Marine Science 65(8), 1387-1391. doi:10.1093/icesjms/fsn154.

Johnson, K., Kerr, S., Side, J., 2012. Accommodating wave and tidal energy - Control and decision in Scotland. Ocean \& Coastal Management 65, 26-33. doi:10.1016/j.ocecoaman. 2012.04.018.

Langhamer, O., Wilhelmsson, D., Engstrom, J., 2009. Artificial reef effect and fouling impacts on offshore wave power foundations and buoys - a pilot study. Estuarine, Coastal and Shelf Science 82(3), 426-432. doi:10.1016/j.ecss.2009.02.009.

Larsen, J.K., Guillemette, M., 2007. Effects of wind turbines on flight behaviour of wintering common eiders: implications for habitat use and collision risk. Journal of Applied Ecology 44(3), 516-522. doi:10.1111/j.1365-2664.2007.01303.x.

Lindeboom, H.J., Kouwenhoven, H.J., Bergman, M.J.N., Bouma, S., Brasseur, S., Daan, R., Fijn, R.C., De Haan, D., Dirksen, S., Van Hal, R., Hille Ris Lambers, R., Ter Hofstede, R., Krijgsveld, K.L., Leopold, M., Scheidat, M., 2011. Short-term ecological effects of an offshore wind farm in the Dutch coastal zone; a compilation. Environmental Research Letters 6, 1-13. doi:10.1088/1748-9326/6/3/035101.

Linley, E.A.S., Wilding, T.A., Black, K., Hawkins, A.J.S., Mangi, S., 
2007. Review of the reef effects of offshore wind farm structures and their potential for enhancement and mitigation. Technical Report Contract No: RFCA/005/0029P. Report from PML Applications Ltd and the Scottish Association for Marine Science to the Department for Business, Enterprise and Regulatory Reform (BERR). P. 132.

Maar, M., Bolding, K., Petersen, J.K., Hansen, J.L.S., Timmermann, K., 2009. Local effects of blue mussels around turbine foundations in an ecosystem model of Nysted off-shore wind farm, Denmark. Journal of Sea Research 62, 159-174. doi:10.1016/j . seares.2009.01.008.

Madariaga, A., Martinez de Alegria, I., Martin, J., Eguia, P. Ceballos, S., 2012. Current facts about offshore wind farms. Renewable and Sustainable Energy Reviews 16(5), 3105-3116. doi:10.1016/j.rser.2012.02.022.

Main(e) International Consulting, 2012. Floating offshore wind foundations: industry consortia and projects in the United States, Europe and Japan. Technical Report. Main(e) International Consulting. P. 40.

Marchand, M., Sanchez-Arcilla, A., Ferreira, M., Gault, J., Jimnez, J.A., Markovic, M., Mulder, J.P.M., van Rijn, L.C., Stanica, A., Sulisz, W., Sutherland, J., 2011. Concepts and science for coastal erosion management - An introduction to the Conscience framework. Ocean \& Coastal Management 54(12), 859866. doi:10.1016/j.ocecoaman.2011.06.005.

Margheritini, L., Hansen, A.M., Frigaard, P., 2012. A method for EIA scoping of wave energy converters - based on classification of the used technology. Environmental Impact Assessment Review 32(1), 33-44. doi:10.1016/j.eiar.2011.02.003.

Martins, G.M., Thompson, R.C., Neto, A.I., Hawkins, S.J., Jenkins, S.R., 2010. Enhancing stocks of the exploited limpet Patella candei d'Orbigny via modifications in coastal engineering. Biological Conservation 143(1), 203-211. doi:10.1016/j.biocon.2009.10. 004

Masden, E.A., Fox, A.D., Furness, R.W., Bullman, R., Haydon, D.T., 2010. Cumulative impact assessments and bird/wind farm interactions: Developing a conceptual framework. Environmental Impact Assessment Review 30(1), 1-7. doi:10.1016/j . eiar. 2009. 05.002.

Masden, E.A., Haydon, D.T., Fox, A.D., Furness, R.W., Bullman, R., Desholm, M., 2009. Barriers to movement: impacts of wind farms on migrating birds. ICES Journal of Marine Science 66(4), 746-753. doi:10.1093/icesjms/f sp031.

McMurray, G.R., 2008. Ecological Effects of Wave Energy Development in the Pacific Northwest: A Scientific Workshop (October 11-12, 2007). NOAA Technical Memorandum NMFS-F/SPO-92. chapter Wave energy ecological effects workshop: Ecological assessment briefing paper. pp. 25-66.

Michel, J., Dunagan, H., Boring, C., Healy, E., Evans, W., Dean, J.M., McGillis, A., Hain, J., 2007. Worldwide Synthesis and Analysis of Existing Information Regarding Environmental Effects of Alternative Energy Uses on the Outer Continental Shelf. Technical Report. U.S. Department of the Interior Minerals Management Service. Herndon. P. 254.

Mueller-Blenkle, C., McGregor, P.K., Gill, A.B., Andersson, M.H., Metcalfe, J., Bendall, V., Sigray, P., Wood, D., Thomsen, F., 2010. Effects of Pile-driving Noise on the Behaviour of Marine Fish. Technical Report. COWRIE. P. 62.

Mulder, J.P.M., Hommes, S., Horstman, E.M., 2011. Implementation of coastal erosion management in the Netherlands. Ocean \& Coastal Management 54(12), 888-897. doi:10.1016/j.ocecoaman. 2011.06 .009$.

Mulder, J.P.M., Nederbragt, G.J., Steetzel, H.J., van Koningsveld, M., Wang, Z.B., 2006. Different implementation scenario's for the large scale coastal policy of the Netherlands, in: Proceedings $30^{\text {th }}$ International Conference on Coastal Engineering, San Diego, USA. pp. 1705-1717.

Norling, P., Kautsky, N., 2008. Patches of the mussel mytilus sp. are islands of high biodiversity in subtidal sediment habitats in the baltic sea. Aquatic biology 4(1), 75-87. doi:10.3354/ab00096.

Normandeau, E., Tricas, T., Gill, A., 2011. Effects of EMFs from
Undersea Power Cables on Elasmobranchs and Other Marine Species. Technical Report. U.S. Dept. of the Interior, Bureau of Ocean Energy Management, Regulation, and Enforcement. Pacific OCS Region, Camarillo, CA,. P. 426.

Olsgard, F., Gray, J.S., 1995. A comprehensive analysis of the effects of offshore oil and gas exploration and production on the benthic communities of the norwegian continental shelf. Marine Ecology Progress Series 122, 277-306.

O'Rourke, F., Boyle, F., Reynolds, A., 2010. Marine current energy devices: Current status and possible future applications in Ireland. Renewable and Sustainable Energy Reviews 14(3), 10261036. doi:10.1016/j.rser.2009.11.012.

OSPAR, 2008. Guidance on Environmental Considerations for Offshore Wind Farm Development. Technical Report. OSPAR. P. 19.

Pelc, R., Fujita, R.M., 2002. Renewable energy from the ocean. Marine Policy 26, 471-479.

Petersen, I.K., Christensen, T.K., Kahlert, J., Desholm, M., Fox, A.D., 2006. Final results of bird studies at the offshore wind farms at Nysted and Horns Rev, Denmark,. Technical Report. NERI Report. Commissioned by DONG energy and Vattenfall A/S. P. 166 .

Petersen, J.K., Malm, T., 2006. Offshore windmill farms: Threats to or possibilities for the marine environment. Ambio 35(2), 75-80. doi:10.1579/0044-7447(2006)35[75: OWFTT0]2.0.CO;2.

Polagye, B., Cleve, B.V., Copping, A., Kirkendall, K. (Eds.), 2011. Environmental Effects of Tidal Energy Development, Proceedings of NOAA Scientific Workshop March 22-25, 2010. P. 190.

Rye, J.H., Gilles, A., Verfuß, U., 2008. European Cetacean Societys 21st Annual Conference. San Sebastian, Spain. chapter Linking wind farms and harbour porpoises: a review of methods. p. 70 .

Samuel, Y., Morreale, S.J., Clark, C.W., Greene, C.H., Richmond, M.E., 2005. Underwater, low frequency noise in a coastal sea turtle habitat. Journal of the Acoustical Society of America 117(3), 1465-1472. doi:10.1121/1.1847993.

Seaman, W., 2007. Artificial habitats and the restoration of degraded marine ecosystems and fisheries. Hydrobiologia 580, 143155. doi:10.1007/s10750-006-0457-9.

SEL, 2010. Avoiding Conflicts in the Marine Environment, LINKs Report on Effective Marine Planning for Marine Renewables Energy in Scotland. Technical Report. Scottish Environment Link, Perth, Scotland,. P. 20.

Shields, M.A., Woolf, D.K., Grist, E.P.M., Kerr, S.A., Jackson, A.C., Harris, R.E., Bell, M.C., Beharie, R., Want, A., Osalusi, E., Gibb, S.W., Side, J., 2011. Marine renewable energy: The ecological implications of altering the hydrodynamics of the marine environment. Ocean \& Coastal Management 54(1), 2-9. doi:10.1016/j.ocecoaman.2010.10.036.

Simas, T., Moura, A., Batty, R., Wilson, B., Thompson, D., Lonergan, M., Norris, J., 2010. Uncertainties and road map. Technical Report. European Commission. P. 22.

Smith, H.C.M., Pearce, C., Millar, D.L., 2012. Further analysis of change in nearshore wave climate due to an offshore wave farm: An enhanced case study for the wave hub site. Renewable Energy 40(1), 51-64. doi:10.1016/j.renene.2011.09.003.

Stegnestam, L., 1999. Environmental Performance Indicators: A Second Edition. Technical Report. The World Bank Environment Department. Environmental Economics Series, p. 50.

Stenberg, C., Van Deurs, M., Stottrup, J., Mosegaard, H., Grome, T., Dinesen, G., Christensen, A., Jesen, H., Kaspersen, M., Berg, C.W., Leonhard, S.B., Skov, H., Pedersen, J., Hvidt, C.B., Klaustrup, M., 2011. Effect of the Horns Rev 1 Offshore Wind Farm on Fish Communities. Follow-up Seven Years after Construction. Technical Report. DTU Aqua. P. 99.

Sutherland, W.J., Bailey, M.J., Bainbridge, I.P., Brereton, T., Dick, J.T.A., Drewitt, J., Dulvy, N.K., Dusic, N.R., Freckleton, R.P., Gaston, K.J., Gilder, P.M., Green, R.E., Heathwaite, A.L., Johnson, S.M., Macdonald, D.W., Mitchell, R., Osborn, D., Owen, R.P., Pretty, J., Prior, S.V., Prosser, H., Pullin, A.S., Rose, P., Stott, A., Tew, T., Thomas, C.D., Thompson, D.B.A., Vickery, J.A., Walker, M., Walmsley, C., Warrington, S., Watkinson, A.R., 
Williams, R.J., Woodroffe, R., Woodroof, H.J., 2008. Future novel threats and opportunities facing UK biodiversity identified by horizon scanning. Journal of Applied Ecology 45(3), 821-833. doi:10.1111/j.1365-2664.2008.01474.x

Talisman, 2004. Environmental statement of the Beatrice Wind Farm Demonstrator Project. Technical Report. Talisman Energy (UK) Limited, Aberdeen. P. 422.

Thomsen, F., Ludemann, K., Kafemann, R., Piper, W., 2006. Effects of Offshore Wind Farm Noise on Marine Mammals and Fish. Technical Report. Biola, Hamburg, Germany, on behalf of COWRIE Ltd., Newbury, UK. P. 62.

Thresher, R., Musial, W., 2010. Ocean renewable energys potential role in supplying future electrical energy needs. The Oceanography Society 23(2), 16-21.

Troost, T., 2008. Estimating the frequency of bird collisions with wind turbines at sea, Guidelines for using the spreadsheet Bird collisions Deltares v1-0.xls. Technical Report. Deltares. P. 25.

Tuebke, A., Hernandez Guevara, H., 2011. Techno-economic analysis of key renewable energy technologies (PV, CSP and wind). Technical Report. Publications Office of the European Union, Luxembourg (Luxembourg). P. 42.

USDOE, 2009. Report to Congress on the Potential Environmental Effects of Marine and Hydrokinetic Energy Technologies. Technical Report. US department of Energy. P. 143.

Van Koningsveld, M., Damsma, T., Van der Hout, R., Van Wiechen, J., De Boer, G.J., 2013. Openearth: A knowledge management workflow for dredging projects. Terra et Aqua 131(1), 3-14. URL: https://www.iadc-dredging.com/ul/cms/ terraetaqua/document/3/7/3/373/373/1/terra131-1.pdf.

Van Koningsveld, M., Davidson, M.A., Huntley, D.A., 2005a. Matching Science with Coastal Management Needs: The Search for Appropriate Coastal State Indicators. Journal of Coastal Research 21(3), 399-411. doi:10.2112/03-0076.1.

Van Koningsveld, M., Davidson, M.A., Huntley, D.A., Medina, R., Aarninkhof, S.G.J., Jimenez, J., Ridgewell, J., De Kruif, A., 2007. A critical review of the CoastView project: Recent and future developments in coastal management video systems. Coastal Engineering 54(6-7), 567-576. doi:10.1016/j.coastaleng.2007.01.006

Van Koningsveld, M., Lescinski, J., 2007. Decadal scale performance of coastal maintenance in the Netherlands. Shore and Beach Vol. 75 No. 1 (Winter 2007), 20-36.

Van Koningsveld, M., Mulder, J.P.M., 2004. Sustainable Coastal Policy Developments in the Netherlands. A Systematic Approach Revealed. Journal of Coastal Research 20(2), 375-385. doi:10. 2112/1551-5036(2004)020 [0375:SCPDIT] 2.0.CO; 2 .

Van Koningsveld, M., Stive, M.J.F., Mulder, J.P.M., 2005b. Balancing research efforts and management needs. A challenge to coastal engineering., in: Proceedings of the 29th Int Conf. of Coast. Eng. Lisbon, pp. 2985-2997.

Van Koningsveld, M., Stive, M.J.F., Mulder, J.P.M., De Vriend, H.J., Dunsbergen, D.W., Ruessink, B.G., 2003. Usefulness and Effectiveness of Coastal Research. A Matter of perception? Journal of Coastal Research 19, 441-461.

Vize, S., Adnitt, C., Staniland, R., Everard, J., Sleigh, A., Cappell, R., McNulty, S., Budd, M., Bonnon, I., Carey, J., 2008. Review of Cabling Techniques and Environmental Effects Applicable to the Offshore Wind Farm Industry. Technical Report. Technical Report prepared by Royal Haskoning and BOMEL Ltd. for the Department of Business, Enterprise and Regulatory Reform (BERR). P 164.

Wilhelmsson, D., Malm, T., Ohman, M.C., 2006. The influence of offshore windpower on demersal fish. ICES Journal of Marine Science 63, 775-784. doi:10.1016/j.ices jms. 2006.02.001.

Wilhelmsson, D., Malm, T., Thompson, R., Tchou, J., Sarantakos, G., McCormick, N., Luitjens, S., Gullstr om, M., Edwards, J.K.P., Amir, O., Dubi, A. (Eds.), 2010. Greening blue energy: Identifying and managing the biodiversity risks and opportunities of offshore renewable energy. IUCN, Gland, Switserland. P. 102.

Woolf, D.K., 2011. Environment, Regulation and Legislation -WP2 of ORECCA project. Technical Report. Environmental Research Institute, University of the Highlands and Islands North Highland
College (ERI, UHI-NHC). P. 44.

Zucco, C., Wende, W., Merck, T., K ochling, I., K oppel, J., 2006. Ecological Research on Offshore Wind Farms: International Exchange of Experiences. PART B: Literature Review of Ecological Impacts. Technical Report. Federal Agency for Nature Conservation, Bonn, Germany,. P. 290.

1260

\section{Acronyms}

BACI Before-After Control-Impact

DPSIR Drivers-Pressures-Status-Impacts-Response

EIA Environmental Impact Assessment

EMF Electro-Magnetic Fields

EMP Environmental Management Plan

ES Environmental Statement

ESI Environmental State Indicators

FoR Frame of Reference

MRE Marine Renewable Energy

PDCA Plan-Do-Check-Act

QSC Quantitative State Concept 